Article

\title{
New Spirotetronate Antibiotics, Lobophorins $H$ and I, from a South China Sea-Derived Streptomyces sp. 12A35
}

\author{
Hua-Qi Pan ${ }^{1,2}$, Song-Ya Zhang ${ }^{2}$, Nan Wang ${ }^{2}$, Zhan-Lin Li ${ }^{1}$, Hui-Ming Hua ${ }^{1, *}$, \\ Jiang-Chun $\mathrm{Hu}^{2, *}$ and Shu-Jin Wang ${ }^{2}$
}

1 Department of Natural Products Chemistry, Shenyang Pharmaceutical University, Shenyang 110016, China; E-Mails: panhq@iae.ac.cn (H.-Q.P.); lz11030@hotmail.com (Z.-L.L.)

Institute of Applied Ecology, Chinese Academy of Sciences, Shenyang 110016, China;

E-Mails: zsykk123@163.com (S.-Y.Z.); wangn@iae.ac.cn (N.W.)

* Authors to whom correspondence should be addressed; E-Mails: huimhua@163.com (H.-M.H.); hujc@iae.ac.cn (J.-C.H.); Tel.: +86-24-2398-6465 (H.-M.H.); +86-24-8397-0386 (J.-C.H.); Fax: +86-24-2398-6460 (H.-M.H.); +86-24-8397-0300 (J.-C.H.).

Received: 4 July 2013; in revised form: 12 August 2013 / Accepted: 22 August 2013 /

Published: 15 October 2013

\begin{abstract}
Strain 12A35 was isolated from a deep-sea sediment collected from the South China Sea and showed promising antibacterial activities. It was identified as Streptomyces sp. by the $16 \mathrm{~S}$ rDNA sequence analysis. Bioassay-guided fractionation using HP20 adsorption, flash chromatography over silica gel and octadecylsilyl (ODS) and semi-preparative HPLC, led to the isolation and purification of five metabolites from the fermentation culture of 12A35. Two new spirotetronate antibiotics, lobophorins $\mathrm{H}(\mathbf{1})$ and $\mathrm{I}(\mathbf{2})$, along with three known analogues, $O$ - $\beta$-kijanosyl-( $\rightarrow 17)$-kijanolide $(3)$, lobophorins B (4) and F (5) were characterized by 1D, 2D-NMR and MS data. These compounds exhibited significant inhibitory activities against Bacillus subtilis. Compounds $\mathbf{1}$ and $\mathbf{5}$ exhibited moderate activities against Staphylococcus aureus. In particular, the new compound lobophorin $\mathrm{H}$ (1) showed similar antibacterial activities against B. subtilis CMCC63501 to ampicillin.
\end{abstract}

Keywords: lobophorins; spirotetronate antibiotics; antimicrobial; Streptomyces; South China Sea-derived actinomycete 


\section{Introduction}

Infectious disease is one of the most deadly diseases threatening public health. Meanwhile, drug-resistant bacteria are steadily rising, increasing the difficulty of treatment. Thus, an efficient way to address this issue is to develop new antibiotics both to help to overcome the antibiotic resistance and to treat new pathogenic diseases. Nowadays, natural products from marine-derived microorganisms have been an important source of novel lead structures for drug discovery. Marine actinomycetes are one of the most efficient groups of secondary metabolite producers. Many intriguing compounds with potent and various bioactivities have been found from marine microbes for lead compounds [1]. For instance, marinisporolides $\mathrm{A}$ and $\mathrm{B}$ were polyene macrolides isolated from the culture of an actinomycete from a new genus Marinispora. Marinisporolide A showed modest activity against Candida albicans [2]. The deep-sea-derived Streptomyces sp. SCSIO 03032 was capable of producing new bisindole alkaloids, spiroindimicins A-D, which exhibited moderate cytotoxicities against several cancer cell lines [3].

During our continuous screening for new antibiotics, the organic extract of the fermentation broth of a deep-sea-derived actinobacterial strain 12A35 showed potent antibacterial activities. Five spirotetronate antibiotics were isolated from an actinomycete $12 \mathrm{~A} 35$ as a member of the genus Streptomyces by $16 \mathrm{~S}$ rDNA analysis. Two compounds were determined to be new lobophorin analogues, designated as lobophorins $\mathrm{H}(\mathbf{1})$ and I (2), and the other three were characterized as known

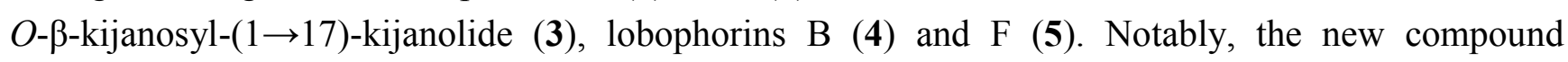
lobophorin H (1) showed similar antibacterial activities against Bacillus subtilis to ampicillin as a positive control drug.

\section{Results and Discussion}

\subsection{Taxonomy of the Strain $12 A 35$}

The 16S rDNA of producing strain 12A35 was polymerase chain reaction (PCR) amplified and sequenced. The strain 12A35 16S ribosomal RNA gene was submitted in the GenBank Database with the accession number KF313921. Sequence analysis showed that 16S rRNA gene sequence of 12A35 to be most similar to those of Streptomyces pactum NBRC $13433^{\mathrm{T}}$, Streptomyces olivaceus NBRC $12805^{\mathrm{T}}$, and Streptomyces parvulus NBRC $13193^{\mathrm{T}}$, with sequence identities of $100 \%, 100 \%$, and $99.33 \%$, respectively. The phylogenetic tree generated by a neighbor-joining method based on $16 \mathrm{~S}$ rRNA gene sequence clearly revealed the evolutionary relationship of the strain 12A35 with a group of Streptomyces species (Figure 1). So, this strain was designated as Streptomyces sp. 12A35. 
Figure 1. Phylogenetic tree of $16 \mathrm{~S}$ rDNA sequences of $12 \mathrm{~A} 35$ strain by the neighbor-joining method.

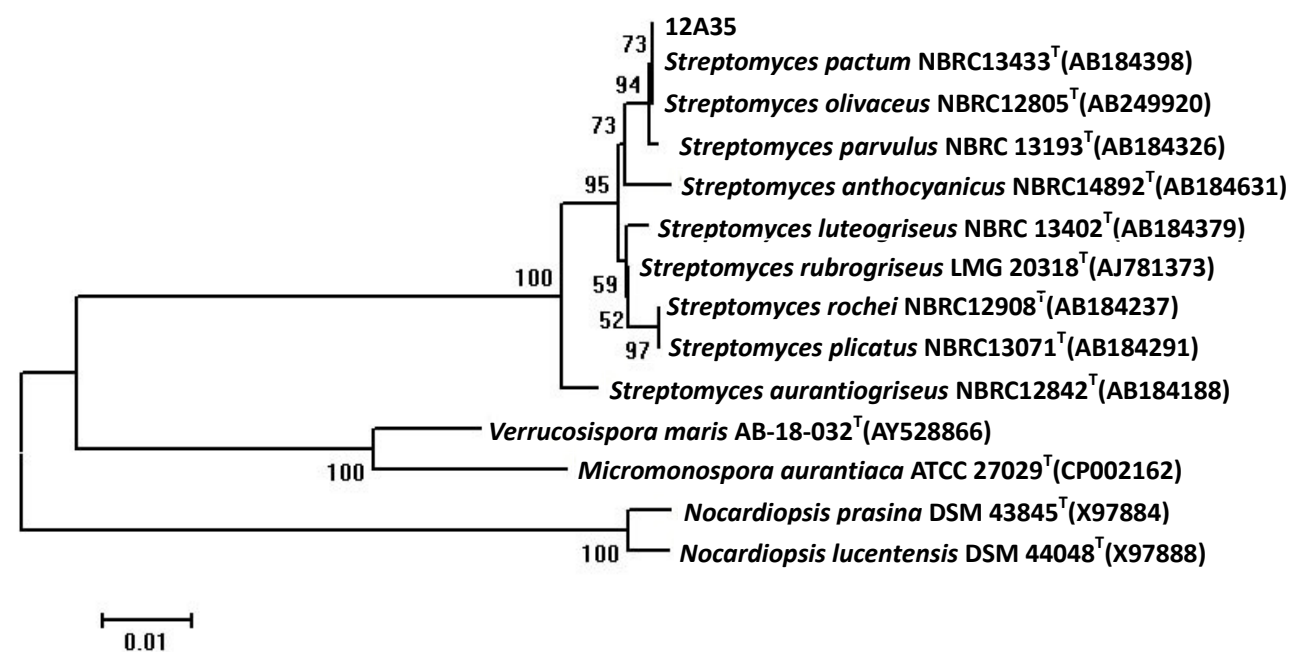

\subsection{Structure Determination}

Compound 1 was obtained as a white powder. Its high-resolution electrospray ionization mass spectrometry (HRESIMS) exhibited a $[\mathrm{M}-\mathrm{H}]^{-}$ion at $\mathrm{m} / \mathrm{z} 1183.5807$, corresponding to a molecular formula of $\mathrm{C}_{61} \mathrm{H}_{88} \mathrm{~N}_{2} \mathrm{O}_{21}$, with 19 degrees of unsaturation. The ${ }^{1} \mathrm{H}$ NMR (600 $\mathrm{MHz}, \mathrm{CDCl}_{3}$ ) spectrum (Table 1) exhibited four methyl singlets at $\delta 1.35,1.45,1.61,1.59$ and seven methyl doublets at $\delta 0.64$, $1.09,1.16,1.20,1.25,1.26,1.36$, two methoxy groups at $\delta 3.41$ and 3.72 , five olefinic protons at $\delta 5.17,5.28,5.38,5.73,6.56$ and one aldehyde at $\delta 9.51$. The ${ }^{13} \mathrm{C}$ NMR (150 MHz, $\left.\mathrm{CDCl}_{3}\right)($ Table 1) and HSQC spectra revealed 61 carbon signals, including four carbonyls (including an aldehyde), ten olefinic carbons, four sugar anomeric carbons, eleven methyls. The ${ }^{1} \mathrm{H}$ and ${ }^{13} \mathrm{C}$ NMR spectra readily indicated the presence of four 2,6-dideoxysugar units through easily identifiable signals for anomeric and 6-methyl protons and carbons. The four monosaccharide moieties were identified as two digitoxose, one 4-O-methyl-digitoxose and one kijanose by the interpretation of ${ }^{1} \mathrm{H}-{ }^{1} \mathrm{H}$ COSY, HMQC and HMBC spectra. The remaining 33 signals were suggestive of a spiroteronate skeleton [4,5]. Further, compound 1 showed similar ${ }^{1} \mathrm{H}$ and ${ }^{13} \mathrm{C}$ NMR spectra to lobophorin B (4) except for the hydroxymethyl signals at C-22 [4]. The oxygenated methylene $\left(\delta_{\mathrm{H}} 4.22(2 \mathrm{H}, \mathrm{m}, \mathrm{H}-32)\right.$ and $\delta_{\mathrm{C}} 64.9$ (C-32)) in lobophorin B was replaced by an aldehyde group at $\delta_{\mathrm{H}} 9.51(1 \mathrm{H}, \mathrm{s}, \mathrm{H}-32)$ and $\delta_{\mathrm{C}} 193.3$ (C-32) in 1, which resulted downfield shift of $\mathrm{H}-21$ proton signal from $\delta 5.50$ to $\delta 6.55$. The HMBC correlations (Figure 2) from proton signals at $\delta_{\mathrm{H}} 9.51(1 \mathrm{H}, \mathrm{s}, \mathrm{H}-32)$ to $\delta_{\mathrm{C}} 144.6(\mathrm{C}-22)$ and $25.2(\mathrm{C}-23)$, as well as from $\delta_{\mathrm{H}} 6.55(1 \mathrm{H}, \mathrm{s}, \mathrm{H}-21)$ to $\delta_{\mathrm{C}} 193.3(\mathrm{C}-32)$, confirmed the aldehyde group located at $\mathrm{C}-22$ in compound 1, designated as lobophorin $\mathrm{H}$ (Figure 3). Furthermore, the similar coupling constant values of $\mathbf{1}$ to lobophorin B indicated the same relative stereochemistry [5]. The relative configuration of anomeric carbon of the sugars was easily determined to be $\alpha$-configuration for sugars $\mathrm{A}$ and $\mathrm{B}$ and $\beta$-configuration for sugars $\mathrm{C}$ and $\mathrm{D}$ from the coupling constants for anomeric protons. The NOESY correlations between H-5/H-9, H-8/H-9, H-10/H-6, H-10/H-29, H-13/H-15 and H-16/H-30 supported the above relative stereochemistry. 
Table 1. ${ }^{1} \mathrm{H}$ and ${ }^{13} \mathrm{C}$ NMR data of compounds $\mathbf{1 - 4}$ in $\mathrm{CDCl}_{3}$.

\begin{tabular}{|c|c|c|c|c|c|c|c|}
\hline \multirow{2}{*}{ Position } & \multicolumn{2}{|r|}{1} & \multicolumn{2}{|r|}{2} & \multirow{2}{*}{$\frac{3}{{ }^{8} \mathrm{C}}$} & \multirow{2}{*}{$\begin{array}{c}4 \\
{ }^{8} \mathrm{C}\end{array}$} & \multirow{2}{*}{$\frac{\text { Lobophorin F [6] }}{{ }^{\delta} \mathrm{C}}$} \\
\hline & ${ }^{8} \mathrm{C}$ & ${ }^{\delta} \mathrm{H}(J$ in $\mathrm{Hz})$ & ${ }^{8} \mathrm{C}$ & ${ }^{\delta} \mathrm{H}(J$ in $\mathrm{Hz})$ & & & \\
\hline 1 & 166.71 & & 167.24 & & 167.12 & 167.23 & 167.3 \\
\hline 2 & 101.68 & & 101.85 & & 101.89 & 101.76 & 101.9 \\
\hline 3 & 206.47 & & 206.07 & & 206.43 & 206.33 & 206.3 \\
\hline 4 & 50.93 & & 50.90 & & 51.02 & 50.92 & 51.0 \\
\hline 5 & 43.11 & $2.00(\mathrm{~m})$ & 43.20 & $1.99(\mathrm{~m})$ & 42.79 & 43.10 & 43.4 \\
\hline 6 & 31.28 & $1.61(\mathrm{~m})$ & 31.29 & $1.61(\mathrm{~m})$ & 31.19 & 31.30 & 31.2 \\
\hline 7 & 41.66 & $1.58(\mathrm{~m}), 1.50(\mathrm{~m})$ & 41.73 & $1.59(\mathrm{~m}), 1.51(\mathrm{~m})$ & 41.72 & 41.69 & 41.9 \\
\hline 8 & 34.37 & $2.22(\mathrm{~m})$ & 34.98 & $1.89(\mathrm{~m})$ & 34.71 & 34.39 & 34.5 \\
\hline 9 & 84.08 & $3.44(\mathrm{~m})$ & 85.57 & $3.55(\mathrm{dd}, 10.9,5.4)$ & 76.08 & 84.16 & 86.7 \\
\hline 10 & 38.39 & $2.08(\mathrm{~m})$ & 38.37 & $2.15(\mathrm{~m})$ & 39.22 & 38.42 & 38.2 \\
\hline 11 & 125.97 & $5.73(\mathrm{~d}, 10.6)$ & 124.98 & $5.71(\mathrm{~d}, 10.9)$ & 125.51 & 125.84 & 125.9 \\
\hline 12 & 126.29 & $5.38(\mathrm{~m})$ & 127.18 & $5.38(\mathrm{~d}, 9.7)$ & 126.51 & 126.45 & 126.6 \\
\hline 13 & 53.24 & $3.46(\mathrm{~m})$ & 52.98 & $3.48(\mathrm{~m})$ & 53.17 & 53.15 & 53.1 \\
\hline 14 & 135.92 & & 135.45 & & 135.83 & 135.73 & 135.7 \\
\hline 15 & 123.22 & $5.17(\mathrm{~d}, 9.2)$ & 123.59 & $5.16(\mathrm{~d}, 9.3)$ & 123.32 & 123.34 & 123.5 \\
\hline 16 & 30.02 & $2.34(\mathrm{~m}), 1.71(\mathrm{~m})$ & 30.94 & $2.34(\mathrm{~m}), 2.25(\mathrm{~m})$ & 31.08 & 30.03 & 31.2 \\
\hline 17 & 78.69 & $4.22(\mathrm{~m})$ & 78.33 & $4.19(\mathrm{~m})$ & 78.47 & 78.36 & 78.9 \\
\hline 18 & 139.46 & & 137.09 & & 137.03 & 137.08 & 136.7 \\
\hline 19 & 116.72 & $5.28(\mathrm{~d}, 10.5)$ & 119.17 & $5.11(\mathrm{~d}, 10.9)$ & 119.23 & 119.19 & 119.9 \\
\hline 20 & 41.24 & $3.80(\mathrm{~d}, 11.1)$ & 40.17 & $3.85(\mathrm{~d}, 10.9)$ & 40.18 & 40.17 & 40.4 \\
\hline 21 & 148.12 & $6.56(\mathrm{~s})$ & 121.52 & $5.49(\mathrm{~s})$ & 121.43 & 121.52 & 120.6 \\
\hline 22 & 144.59 & & 141.24 & & 141.35 & 141.28 & 137.8 \\
\hline 23 & 25.36 & $3.01(\mathrm{~m})$ & 27.87 & $2.66(\mathrm{~m})$ & 27.93 & 27.95 & 31.9 \\
\hline 24 & 34.80 & $2.36(\mathrm{~m}), 1.89(\mathrm{~m})$ & 35.31 & $2.37(\mathrm{~m}), 1.82(\mathrm{~m})$ & 35.33 & 35.35 & 35.5 \\
\hline 25 & 82.94 & & 83.32 & & 83.24 & 83.30 & 83.3 \\
\hline 26 & 200.97 & & 201.37 & & 201.49 & 201.63 & 201.7 \\
\hline $27\left(4-\mathrm{CH}_{3}\right)$ & 15.13 & $1.62(\mathrm{~s}, 3 \mathrm{H})$ & 14.98 & $1.59(\mathrm{~s}, 3 \mathrm{H})$ & 15.03 & 15.05 & 15.1 \\
\hline $28\left(6-\mathrm{CH}_{3}\right)$ & 22.23 & $0.64(\mathrm{~d}, 4.9)$ & 22.15 & $0.63(\mathrm{~d}, 5.8)$ & 22.28 & 22.23 & 22.2 \\
\hline $29\left(8-\mathrm{CH}_{3}\right)$ & 14.11 & $1.09(\mathrm{~d}, 6.4)$ & 14.39 & $1.09(\mathrm{~d}, 7.0)$ & 12.99 & 14.12 & 14.6 \\
\hline $30\left(14-\mathrm{CH}_{3}\right)$ & 13.73 & $1.35(\mathrm{~s}, 3 \mathrm{H})$ & 13.70 & $1.31(\mathrm{~s}, 3 \mathrm{H})$ & 13.70 & 13.70 & 13.8 \\
\hline $31\left(18-\mathrm{CH}_{3}\right)$ & 15.18 & $1.45(\mathrm{~s}, 3 \mathrm{H})$ & 15.03 & $1.45(\mathrm{~s}, 3 \mathrm{H})$ & 15.11 & 15.09 & 15.1 \\
\hline $32(22-C)$ & 193.32 & $9.51(\mathrm{~s})$ & 64.85 & $4.20(\mathrm{~s}, 2 \mathrm{H})$ & 64.93 & 64.89 & 21.8 \\
\hline $33\left(23-\mathrm{CH}_{3}\right)$ & 19.97 & $1.36(\mathrm{~d}, 6.4,3 \mathrm{H})$ & 20.14 & $1.30(\mathrm{~m}, 3 \mathrm{H})$ & 20.18 & 20.18 & 20.2 \\
\hline A1 & 98.00 & $4.78(\mathrm{~d}, 4.7)$ & 99.58 & $4.90(\mathrm{~d}, 2.7)$ & & 97.98 & 99.1 \\
\hline $\mathrm{A} 2$ & 31.02 & $2.30(\mathrm{~m}), 2.35(\mathrm{~m})$ & 34.05 & $2.25(\mathrm{~m}, 2 \mathrm{H})$ & & 30.95 & 33.4 \\
\hline A3 & 66.61 & $4.00(\mathrm{~m})$ & 67.26 & $3.98(\mathrm{~m})$ & & 66.67 & 74.1 \\
\hline A4 & 71.80 & $3.26(\mathrm{dd}, 8.7,3.5)$ & 72.60 & $3.19(\mathrm{~d}, 8.9)$ & & 71.81 & 72.4 \\
\hline A5 & 64.94 & $4.00(\mathrm{~m})$ & 65.23 & $3.82(\mathrm{~m})$ & & 64.95 & 65.0 \\
\hline A6 & 17.72 & $1.26(\mathrm{~d}, 6.0,3 \mathrm{H})$ & 17.69 & $1.30(\mathrm{~m}, 3 \mathrm{H})$ & & 17.71 & 17.7 \\
\hline B1 & 90.97 & $5.13(\mathrm{~m})$ & & & & 90.99 & 96.5 \\
\hline B2 & 34.08 & $2.12(\mathrm{~m}), 1.91(\mathrm{~m})$ & & & & 34.07 & 35.3 \\
\hline B3 & 65.48 & $4.22(\mathrm{~m})$ & & & & 65.53 & 66.9 \\
\hline
\end{tabular}


Table 1. Cont.

\begin{tabular}{|c|c|c|c|c|c|c|c|}
\hline B4 & 82.10 & $3.23(\mathrm{dd}, 7.7,2.3)$ & & & & 82.1 & 72.5 \\
\hline B5 & 62.12 & $3.98(\mathrm{~m})$ & & & & 62.13 & 65.6 \\
\hline B6 & 17.89 & $1.20(\mathrm{~d}, 6.0,3 \mathrm{H})$ & & & & 17.87 & 17.7 \\
\hline $\mathrm{C} 1$ & 98.28 & $4.91(\mathrm{dd}, 9.3,2.0)$ & & & & 98.30 & \\
\hline $\mathrm{C} 2$ & 36.65 & $2.16(\mathrm{~m}), 1.67(\mathrm{~m})$ & & & & 36.64 & \\
\hline $\mathrm{C} 3$ & 63.96 & $4.25(\mathrm{~d}, 2.6)$ & & & & 63.96 & \\
\hline $\mathrm{C} 4$ & 82.10 & $2.84(\mathrm{dd}, 9.2,2.6)$ & & & & 82.05 & \\
\hline $\mathrm{C} 5$ & 68.37 & $3.76(\mathrm{q}, 5.8)$ & & & & 68.37 & \\
\hline $\mathrm{C} 6$ & 18.25 & $1.25(\mathrm{~d}, 6.0,3 \mathrm{H})$ & & & & 18.25 & \\
\hline $\mathrm{C} 4-\mathrm{OCH}_{3}$ & 57.37 & $3.41(\mathrm{~s}, 3 \mathrm{H})$ & & & & 57.37 & \\
\hline D1 & 97.39 & $4.46(\mathrm{dd}, 9.2,1.5)$ & 96.98 & $4.42(\mathrm{dd}, 9.8,1.9)$ & 97.03 & 96.96 & 97.4 \\
\hline D2 & 35.72 & $2.77(\mathrm{~m}), 1.63(\mathrm{~m})$ & 35.65 & $2.75(\mathrm{~m}), 1.59(\mathrm{~m})$ & 35.71 & 35.71 & 35.8 \\
\hline D3 & 91.09 & & 90.98 & & 91.01 & 91.12 & 90.9 \\
\hline D4 & 53.72 & $4.39(\mathrm{~d}, 10.4)$ & 53.66 & $4.35(\mathrm{~d}, 10.1)$ & 53.66 & 53.67 & 53.9 \\
\hline D5 & 69.12 & $3.48(\mathrm{~m})$ & 69.07 & $3.47(\mathrm{~d}, 7.4)$ & 69.07 & 69.05 & 68.9 \\
\hline D6 & 16.97 & $1.16(\mathrm{~d}, 6.0,3 \mathrm{H})$ & 16.94 & $1.16(\mathrm{~d}, 6.4,3 \mathrm{H})$ & 16.97 & 16.97 & 17.0 \\
\hline D3- $-\mathrm{CH}_{3}$ & 25.22 & $1.59(\mathrm{~s}, 3 \mathrm{H})$ & 25.25 & $1.56(\mathrm{~s}, 3 \mathrm{H})$ & 25.28 & 25.27 & 25.3 \\
\hline $\mathrm{D} 4 \mathrm{C}=\mathrm{O}$ & 157.34 & & 157.44 & & 157.35 & 157.38 & 157.4 \\
\hline $\mathrm{D} 4-\mathrm{OCH}_{3}$ & 52.74 & $3.72(\mathrm{~s}, 3 \mathrm{H})$ & 52.72 & $3.72(\mathrm{~s}, 3 \mathrm{H})$ & 52.69 & 52.73 & 52.7 \\
\hline
\end{tabular}

Figure 2. Selected key ${ }^{1} \mathrm{H}-{ }^{1} \mathrm{H}$ COSY and HMBC correlations of lobophorin $\mathrm{H}$ (1).

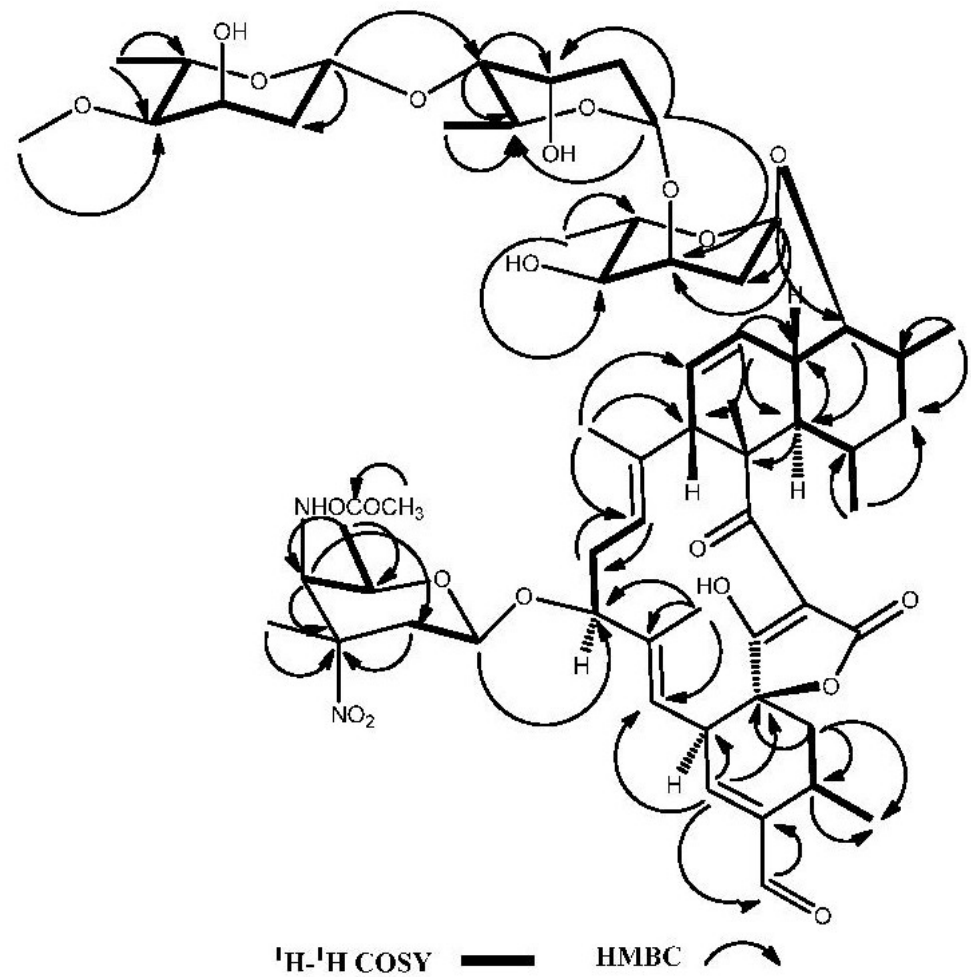

Compound 2 was obtained as a white amorphous powder. The HRESIMS data $(\mathrm{m} / \mathrm{z} 911.4544$ $[\mathrm{M}-\mathrm{H}]^{-}$and $m / z 913.4522[\mathrm{M}+\mathrm{H}]^{+}$) of 2 established the molecular formula to be $\mathrm{C}_{48} \mathrm{H}_{68} \mathrm{~N}_{2} \mathrm{O}_{15}$. The ${ }^{1} \mathrm{H}$ NMR (600 MHz, $\mathrm{CDCl}_{3}$ ) spectrum (Table 1) showed four methyl singlets at $\delta 1.31,1.45,1.56,1.59$ and five methyl doublets at $\delta 0.63,1.09,1.16,1.30,1.30$, a methoxy groups at $\delta 3.72$, one oxygenated 
methylene at $\delta 4.20$ and five olefinic protons at $\delta 5.11,5.16,5.38,5.49,5.71$. The ${ }^{13} \mathrm{C}$ NMR $\left(150 \mathrm{MHz}, \mathrm{CDCl}_{3}\right)($ Table 1) and HSQC spectra revealed 48 carbon signals, including three carbonyls, ten olefinic carbons, two sugar anomeric carbons, nine methyls. According to the ${ }^{1} \mathrm{H}$ and ${ }^{13} \mathrm{C}$ NMR spectral data, compound 2 was determined as an analogue of compound $\mathbf{1}$. Comparing with the ${ }^{1} \mathrm{H}$ and ${ }^{13} \mathrm{C}$ NMR data of lobophorin $\mathrm{B}$ (4), the signals of sugar $\mathrm{B}$ (digitoxose) and sugar $\mathrm{C}$ (4-O-methyl-digitoxose) in lobophorin $\mathrm{B}$ were absent in compound 2 (Table 1). The HMBC correlations between $\delta_{\mathrm{H}} 4.79(\mathrm{H}-1 \mathrm{~A}), 2.25(\mathrm{H}-2 \mathrm{~A})$ and $\delta_{\mathrm{C}} 67.26$ assigned the carbon signal at $\delta 67.26$ to $\mathrm{C}-3 \mathrm{~A}$. In comparison with ${ }^{13} \mathrm{C}-\mathrm{NMR}$ data of lobophorin $\mathrm{F}, 6.8 \mathrm{ppm}$ upfield deglycosidation shift of in $\mathrm{C}-3 \mathrm{~A}$ was consistent with the loss of the sugar $\mathrm{B}$ and $\mathrm{C}$ moieties in 2 . The ${ }^{1} \mathrm{H}$ - and ${ }^{13} \mathrm{C}$-NMR signals of 2 were assigned by HSQC, HMBC and ${ }^{1} \mathrm{H}-{ }^{1} \mathrm{H}$ COSY spectral analyses (Table 1). Based on these MS and NMR data, the structure of 2 was determined to be lobophorin I (Figure 3). Furthermore, the relative stereochemistry could be determined by comparison of NMR data with $\mathbf{1}$.

Figure 3. Chemical structures of compounds 1-5.
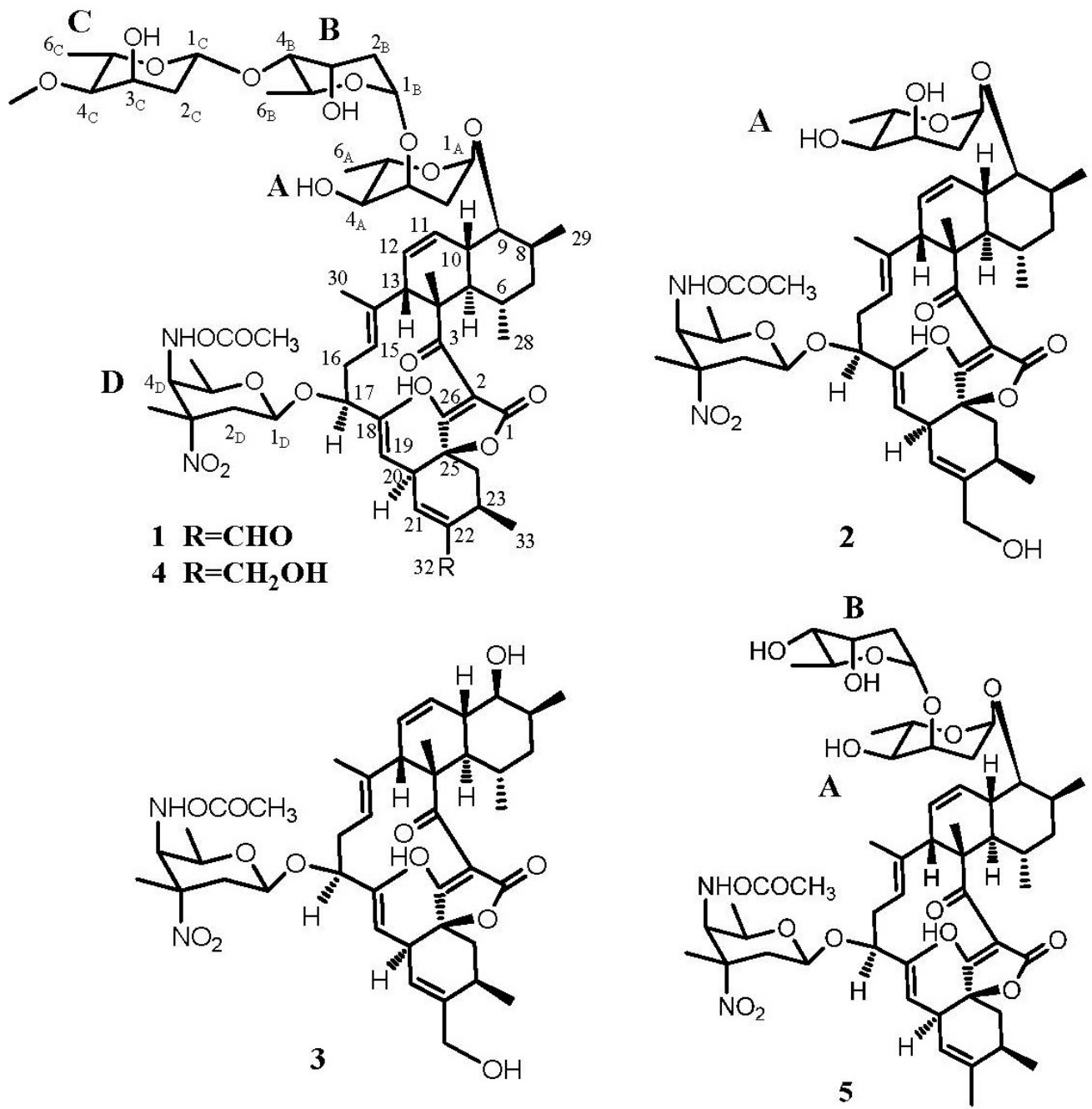

Compound 3 was isolated as a white powder. Its molecular formula was determined as $\mathrm{C}_{42} \mathrm{H}_{58} \mathrm{~N}_{2} \mathrm{O}_{12}$ by HRESIMS ( $\left.m / z 781.3917[\mathrm{M}-\mathrm{H}]^{-}\right)$. By comparing ${ }^{1} \mathrm{H}$ NMR $\left(600 \mathrm{MHz}, \mathrm{CDCl}_{3}\right)$ and ${ }^{13} \mathrm{C}$ NMR $\left(150 \mathrm{MHz}, \mathrm{CDCl}_{3}\right)$ data (Table 1) with those previously reported, 3 was identified as 
$O$ - $\beta$-kijanosyl-(1 $\rightarrow 17)$-kijanolide (Figure 3$)$ which was reported as a methanolysis product of kijanimicin [7]. Compound 3 was found for the first time as a natural product.

Compound 4, white powder, afforded HRESIMS data $\left(\mathrm{m} / z 1185.5970[\mathrm{M}-\mathrm{H}]^{-}\right.$and 1209.5901 $[\mathrm{M}+\mathrm{Na}]^{+}$) consistent with the molecular formula $\mathrm{C}_{61} \mathrm{H}_{90} \mathrm{~N}_{2} \mathrm{O}_{21}$. According to ${ }^{1} \mathrm{H} \mathrm{NMR}(600 \mathrm{MHz}$, $\mathrm{CDCl}_{3}$ ) and ${ }^{13} \mathrm{C}$ NMR (150 MHz, $\mathrm{CDCl}_{3}$ ) (Table 1), 4 was identified as lobophorin B (Figure 3), which was previously found from the fermentation broths of a marine bacterium showed potent antiinflammatory activities in the PMA (Phorbol-Myristate-Acetate)-induced mouse ear edema model [5].

Compound 5 was obtained as a white powder, whose HRESIMS gave the molecular formula $\mathrm{C}_{54} \mathrm{H}_{78} \mathrm{~N}_{2} \mathrm{O}_{17}$ base on quasi-molecular ion peaks at $m / z 1049.5055[\mathrm{M}+\mathrm{Na}]^{+}$and $1025.5203[\mathrm{M}-\mathrm{H}]^{-}$. The ${ }^{1} \mathrm{H}$ NMR $\left(600 \mathrm{MHz}, \mathrm{CDCl}_{3}\right)$ data of $\mathbf{5}$ was identical to those published data of lobophorin $\mathrm{F}$ (Figure 3), which was previously isolated from a Streptomyces sp. SCSIO 01127 and showed antibacterial activities and cytotoxic activities [6].

The spirotetronate antibiotics are a class of natural products that exhibit broad biological activities, including antibacterial, antitumor, antiviral, antimalaria effects and cholesterol biosynthesis inhibition $[5,8,9]$. They feature an unusual macrolide that contains a characteristic tetronic acid (spiro-linked to a cyclohexene ring) conjugated with a trans-decalin system either by a carboxylic ester or a carbonyl group [10]. In order to continue to search for new drugs, these compounds are continually found including kijanimicin [11], tetrocarcins [12], chlorothricin [10], decatromicins [13], saccharocarcins [14], antlermicins [15], versipelostatins [16], arisostatins [17], quartromicins [9] and chrolactomycin [18]. One representative of this group is lobophorins, among which lobophorins A and $\mathrm{B}$ were produced from an alga-associated acintobacterium [5], lobophorins $\mathrm{C}$ and $\mathrm{D}$ were produced by a marine spongerelated Streptomyces [19], and lobophorins E, F and G were isolated from marine-derived Streptomyces [6,20]. The discovery of more spirotetronate antibiotics will throw more light on the structure-activity relationships and potential applications of these compounds.

\subsection{Antimicrobial Activity of Compounds 1-5}

Regarding the results shown in Table 2, the tested lobophorins did not exhibit inhibitory activity on Gram-negative bacteria (E. coli) and fungi (C. albicans, F. moniliforme). Only compounds $\mathbf{1}$ and $\mathbf{5}$ exhibited moderate activities against Staphylococcus aureus ATCC29213 with minimum inhibitory concentrations (MIC) values of 50 and $6.25 \mu \mathrm{g} \cdot \mathrm{mL}^{-1}$, respectively. All the tested compounds exhibited inhibitory activities against Bacillus subtilis CMCC63501. Compounds $\mathbf{1}$ and $\mathbf{4}$ showed strong activities against Bacillus subtilis CMCC63501 with MIC values of 3.13 and $1.57 \mu \mathrm{g} \cdot \mathrm{mL}^{-1}$, respectively, while compounds $\mathbf{2}, \mathbf{3}$ and $\mathbf{5}$ possessed moderate activities against Bacillus subtilis CMCC63501 with MIC values of $6.25,50,50 \mu \mathrm{g} \cdot \mathrm{mL}^{-1}$, respectively. With the increase of the amount of monosaccharide units, the inhibitory activity increased indicating that monosaccharide might play an important role for the antimicrobial activity of lobophorins. These findings support the proposal that the change of the length of saccharide chains alters the biological activity of the natural product, in which the sugars contribute to specific interactions with the biological target [21]. It is noticeable that lobophorin H (1) showed similar antibacterial activities against Bacillus subtilis CMCC63501 to 
ampicillin. Given the significant inhibitory activities against Gram-positive bacteria, lobophorins F (5) and $\mathrm{H}$ (1) may potentially find applications in anti-infective drug development.

Table 2. Minimum inhibitory concentrations for compounds $\mathbf{1}-\mathbf{5}\left(\mu \mathrm{g} \cdot \mathrm{mL}^{-1}\right)$.

\begin{tabular}{cccccc}
\hline Compounds & $\begin{array}{c}\text { S. aureus } \\
\text { ATCC29213 }\end{array}$ & $\begin{array}{c}\text { B. subtilis } \\
\text { CMCC63501 }\end{array}$ & $\begin{array}{c}\text { E. coil } \\
\text { ATCC25922 }\end{array}$ & $\begin{array}{c}\text { C. albicans } \\
\text { ATCC10231 }\end{array}$ & $\begin{array}{c}\text { F. moniliforme } \\
\text { S16 }\end{array}$ \\
\hline $\mathbf{1}$ & 50 & 1.57 & $>100$ & $>200$ & $>200$ \\
$\mathbf{2}$ & $>100$ & 50 & $>100$ & $>200$ & $>200$ \\
$\mathbf{3}$ & 100 & 50 & $>100$ & $>200$ & $>200$ \\
$\mathbf{4}$ & 100 & 3.13 & $>100$ & $>200$ & $>200$ \\
$\mathbf{5}$ & 6.25 & 6.25 & $>100$ & $>200$ & $>200$ \\
ampicillin & 3.13 & 1.57 & 25 & NA & NA \\
nystatin & NA & NA & NA & 6.25 & 25 \\
\hline
\end{tabular}

NA: Not assayed.

\section{Experimental Section}

\subsection{General Experimental Procedures}

The chromatographic silica gel (500-600 mesh) was purchased from Qingdao Ocean Chemical Factory (Qingdao, China) and Diaion HP 20 macroporous resin was purchased from Mitsubishi Chemical Co., Ltd., Tokyo, Japan. RP-HPLC analysis and semi-preparation were conducted using a U3000 HPLC system (Dionex, Sunnyvale, CA, USA) and performed with a C18 YMC-Pack ODS-A column $(5 \mu \mathrm{m}, \varphi 10 \times 250 \mathrm{~mm})$. HRESIMS was recorded on a Bruker QTOF-ESI mass spectrometer. One-dimensional and two-dimensional NMR spectroscopy $\left({ }^{1} \mathrm{H}-\mathrm{NMR},{ }^{13} \mathrm{C}-\mathrm{NMR}\right.$, HSQC, HMBC, ${ }^{1} \mathrm{H}^{-1} \mathrm{H}$ COSY) were conducted with a Bruker AV600 spectrometer (Rheinstetten, Germany). Deuterated NMR solvents were purchased from Cambridge Isotopes (Andover, MA, USA). Specimens of the strains for antimicrobial activity were deposited at the Group of Microbial Biotechnology, Institute of Applied Ecology, Chinese Academy of Sciences.

\subsection{Microorganisms and Fermentation Conditions}

The sediment was collected from the South China Sea at the depth of $2134 \mathrm{~m}\left(17^{\circ} 59.928^{\prime} \mathrm{N}\right.$, $111^{\circ} 36.160^{\prime} \mathrm{E}$ ). To effective isolation of culturable marine actinomycetes by making the culture conditions similar to true marine environment, the strain $12 \mathrm{~A} 35$ was isolated after incubation at $28{ }^{\circ} \mathrm{C}$ for 1 week on modified Gauze's synthetic medium NO. 1 with artificial sea water instead of $\mathrm{NaCl}$ and distilled water (soluble starch $20.0 \mathrm{~g} ; \mathrm{KNO}_{3} 1.0 \mathrm{~g} ; \mathrm{MgSO}_{4} \cdot 7 \mathrm{H}_{2} \mathrm{O} 0.5 \mathrm{~g} ; \mathrm{K}_{2} \mathrm{HPO}_{4} 0.5 \mathrm{~g} ; \mathrm{FeSO}_{4} \cdot 7 \mathrm{H}_{2} \mathrm{O}$ $10.0 \mathrm{mg}$; agar $15.0 \mathrm{~g}$; artificial sea water $1.0 \mathrm{~L}$; adjust $\mathrm{pH}$ 7.0). Genomic DNA isolation, PCR amplification of $16 \mathrm{~S}$ rDNA, and sequencing were performed with conventional methods. Sequence analysis of $16 \mathrm{~S}$ rDNA were performed using BLASTN. Phylogenetic tree were constructed using Neighbor-Joining method of MEGA (version 5.0). Tree topologies were evaluated by bootstrap analysis with 1000 replicates.

The strain 12A35 was maintained on modified Gauze's synthetic medium NO. 1 at $28{ }^{\circ} \mathrm{C}$, and the agar was cut into pieces $(1 \times 1 \mathrm{~cm})$ and inoculated into $5 \times 100 \mathrm{~mL}$ of seed medium (potato sucrose 
broth containing sucrose $20 \mathrm{~g}$, infusion from $200 \mathrm{~g}$ potatoes, artificial sea water $1 \mathrm{~L}$ at $\mathrm{pH} 6.0$ before sterilization) in 500-mL Erlenmeyer flasks, then cultivated at $28{ }^{\circ} \mathrm{C}$ for 2 days with shaking at $180 \mathrm{rpm}$. Seed cultures were transferred into $24 \times 650 \mathrm{~mL}$ production medium in $3.0 \mathrm{~L}$ Erlenmeyer flasks, with an inoculation volume of $3 \%-4 \%(\mathrm{v} / \mathrm{v})$, and incubated under the same conditions for 7 days.

\subsection{Bioactivity-Guided Isolation and Purification}

Fermentation broth $(16 \mathrm{~L})$ of $12 \mathrm{~A} 35$ was centrifuged at $4000 \times \mathrm{g}$ for $30 \mathrm{~min}$. The supernatant was subjected to HP20 macroporous adsorption resin by two-step gradient elution with EtOH/ $\mathrm{H}_{2} \mathrm{O}$ solutions of $10 \%$ and $100 \%$. The EtOH fraction was evaporated to dryness under vacuum with a rotary evaporator. The mycelia were extracted three times with $3 \mathrm{~L}$ acetone and the acetone solution was evaporated to dryness. Two above residues were combined and extracted three times with methanol as the crude extract for further isolation. The crude extract $(30.04 \mathrm{~g})$ were subjected to vacuum flash chromatography over silica gel (500-600 mesh) and gradiently eluted with dichloromethane and methanol at ratios of $(\mathrm{v} / \mathrm{v})$ 100:0, 98:2, 95:5, 90:10, 80:20, 70:30, 60:40, 50:50 and 0:100 to give nine fractions (f1-f9). F4 (yield: $1.77 \mathrm{~g}$ ) obtained by elution with dichloromethane/methanol (90:10, v/v) showed antibacterial activity. F4 was subjected to vacuum flash chromatography over ODS and eluted with $\mathrm{CH}_{3} \mathrm{OH} / \mathrm{H}_{2} \mathrm{O}$ (1:9-10:0), to give ten sub-fractions (rf1-rf10). Sub-fractions rf8 (458 mg) and rf9 (698 mg) with antibacterial activities were combined, and further separated by a semi-preparative HPLC system (Dionex U3000, Sunnyvale, CA, USA) using a C18 YMC-Pack ODS-A column (5 $\mu$ m, $\varphi 10 \times 250 \mathrm{~mm}$ ) eluted with $90 \%$ methanol containing $0.05 \%$ trifluoroacetic acid (TFA) at a flow rate of $2.5 \mathrm{~mL} / \mathrm{min}$ with UV detection at $220 \mathrm{~nm}$. Compounds 1 (18.1 mg), 2 (12.4 mg), 3 (6.3 mg), $4(67.3 \mathrm{mg})$, and $5(11.6 \mathrm{mg})$ were obtained at retention time of $15.2 \mathrm{~min}, 9.6 \mathrm{~min}, 8.9 \mathrm{~min}, 11.5 \mathrm{~min}$, $16.8 \mathrm{~min}$, respectively.

\subsection{Antimicrobial Activity of Compounds $\mathbf{1}-\mathbf{5}$}

Antimicrobial activity of compounds 1-5 were performed as described methods previously [22], and the minimum inhibitory concentrations (MIC) of compounds (1-5) were determined against five microbial strains, including Staphylococcus aureus ATCC 29213, Bacillus subtilis CMCC63501, Escherichia coil ATCC25922, Candida albicans ATCC10231 and Fusarium moniliforme S16. Ampicillin for bacteria and nystatin for fungi were used as positive controls with medium as a negative control.

\section{Conclusions}

Two new spirotetronate antibiotics lobophorins $\mathrm{H}$ (1) and I (2), along with three known analogues, $O$ - $\beta$-kijanosyl-(1 $\rightarrow$ 17)-kijanolide $(\mathbf{3})$, lobophorins $\mathrm{B}(\mathbf{4})$ and $\mathrm{F}(\mathbf{5})$ were isolated and characterized from a deep-sea-derived Streptomyces sp. 12A35. These compounds exhibited significant inhibitory activities against Bacillus subtilis. Compounds $\mathbf{1}$ and $\mathbf{5}$ exhibited moderate activities against Staphylococcus aureus. Notablely, the compound $\mathbf{1}$ showed similar antibacterial activities against Bacillus subtilis to ampicillin as a positive control drug. Our results threw some light on the structure-activity relationships and potential applications of these compounds. 


\section{Acknowledgments}

This work was supported by grants from the National Science Foundation for Young Scientists of China (41006088), National High Technology Research and Development Program of China (863 Program) (No. 2012AA092104, 2011AA09070404), the National Science \& Technology Pillar Program (No. 2011BAE06B04). We are grateful to Wen Li, Ying Peng and Yi Sha of the Shenyang Pharmaceutical University for recording NMR and MS spectra.

\section{Conflicts of Interest}

The authors declare no conflict of interest.

\section{References}

1. Blunt, J.W.; Copp, B.R.; Keyzers, R.A.; Munro, M.H.; Prinsep, M.R. Marine natural products. Nat. Prod. Rep. 2013, 30, 237-323.

2. Kwon, H.C.; Kauffman, C.A.; Jensen, P.R.; Fenical, W. Marinisporolides, polyene-polyol macrolides from a marine actinomycete of the new genus Marinispora. J. Org. Chem. 2008, 74, 675-684.

3. Zhang, W.; Liu, Z.; Li, S.; Yang, T.; Zhang, Q.; Ma, L.; Tian, X.; Zhang, H.; Huang, C.; Zhang, S. Spiroindimicins A-D: New bisindole alkaloids from a deep-sea-derived actinomycete. Org. Lett. 2012, 14, 3364-3367.

4. Mallams, A.K.; Puar, M.S.; Rossman, R.R.; McPhail, A.T.; Macfarlane, R.D.; Stephens, R.L. Kijanimicin. Part 3. Structure and absolute stereochemistry of kijanimicin. J. Chem. Soc. Perkin Trans. 1 1983, 1497-1534.

5. Jiang, Z.-D.; Jensen, P.R.; Fenical, W. Lobophorins A and B, new antiinflammatory macrolides produced by a tropical marine bacterium. Bioorg. Med. Chem. Lett. 1999, 9, 2003-2006.

6. Niu, S.; Li, S.; Chen, Y.; Tian, X.; Zhang, H.; Zhang, G.; Zhang, W.; Yang, X.; Zhang, S.; Ju, J.; et al. Lobophorins $\mathrm{E}$ and $\mathrm{F}$, new spirotetronate antibiotics from a South China Sea-derived Streptomyces sp. SCSIO 01127. J. Antibiot. 2011, 64, 711-716.

7. Mallams, A.K.; Puar, M.S.; Rossman, R.R.; McPhail, A.T.; Macfarlane, R.D. Kijanimicin. 2. Structure and absolute stereochemistry of kijanimicin. J. Am. Chem. Soc. 1981, 103, 3940-3943.

8. Tomita, F.; Tamaoki, T.; Shirahata, K.; Kasai, M.; Morimoto, M.; Ohkubo, S.; Mineura, K.; Ishii, S. Novel antitumor antibiotics, tetrocarcins. J. Antibiot. 1980, 33, 668-670.

9. Kusumi, T.; Ichikawa, A.; Kakisawa, H.; Tsunakawa, M.; Konishi, M.; Oki, T. The structures of quartromicins A1, A2, and A3: Novel macrocyclic antiviral antibiotics possessing four tetronic acid moieties. J. Am. Chem. Soc. 1991, 113, 8947-8948.

10. Jia, X.Y.; Tian, Z.H.; Shao, L.; Qu, X.D.; Zhao, Q.F.; Tang, J.; Tang, G.L.; Liu, W. Genetic characterization of the chlorothricin gene cluster as a model for spirotetronate antibiotic biosynthesis. Chem. Biol. 2006, 13, 575-585. 
11. Waitz, J.A.; Horan, A.; Kalyanpur, M.; Lee, B.K.; Loebenberg, D.; Marquez, J.A.; Miller, G.; Patel, M.G. Kijanimicin (Sch 25663), a novel antibiotic produced by Actinomadura kijaniata SCC 1256. Fermentation, isolation, characterization and biological properties. J. Antibiot. 1981, 34, 1101-1106.

12. Tamaoki, T.; Kasai, M.; Shirahata, K.; Tomita, F. Tetrocarcins E1, E2, F and F-1, new antibiotics. Fermentation, isolation and characterization. J. Antibiot. 1982, 35, 979-984.

13. Momose, I.; Hirosawa, S.; Nakamura, H.; Naganawa, H.; Iinuma, H.; Ikeda, D.; Takeuchi, T. Decatromicins A and B, new antibiotics produced by Actinomadura sp. MK73-NF4. II. Structure determination. J. Antibiot. 1999, 52, 787-796.

14. Horan, A.C.; Shearer, M.C.; Hedge, V.; Beyazova, M.L.; Brodsky, B.C.; King, A.; Berrie, R.; Cardaci, K.; Nimeck, M. A family of novel macrocyclic lactones, the saccharocarcins produced by Saccharothrix aerocolonigenes subsp. antibiotica. I. Taxonomy, fermentation, isolation and biological properties. J. Antibiot. 1997, 50, 126-134.

15. Kobinata, K.; Uramoto, M.; Mizuno, T.; Isono, K. A new antibiotic, antlermicin A. J. Antibiot. 1980, 33, 244-246.

16. Park, H.R.; Furihata, K.; Hayakawa, Y.; Shin-ya, K. Versipelostatin, a novel GRP78/Bip molecular chaperone down-regulator of microbial origin. Tetrahedron Lett. 2002, 43, 6941-6945.

17. Furumai, T.; Takagi, K.; Igarashi, Y.; Saito, N.; Oki, T. Arisostatins A and B, new members of tetrocarcin class of antibiotics from Micromonospora sp. TP-A0316-I. Taxonomy, fermentation, isolation and biological properties. J. Antibiot. 2000, 53, 227-232.

18. Nakai, R.; Kakita, S.; Asai, A.; Chiba, S.; Akinaga, S.; Mizukami, T.; Yamashita, Y. Chrolactomycin, a novel antitumor antibiotic produced by Streptomyces sp. J. Antibiot. 2001, 54, 836-839.

19. Wei, R.B.; Xi, T.; Li, J.; Wang, P.; Li, F.C.; Lin, Y.C.; Qin, S. Lobophorin C and D, new kijanimicin derivatives from a marine sponge-associated actinomycetal srain AZS17. Mar. Drugs 2011, 9, 359-368.

20. Chen, C.; Wang, J.; Guo, H.; Hou, W.; Yang, N.; Ren, B.; Liu, M.; Dai, H.; Liu, X.; Song, F.; et al. Three antimycobacterial metabolites identified from a marine-derived Streptomyces sp. MS100061. Appl. Microbiol. Biotechnol. 2013, 97, 3885-3892.

21. Griffith, B.R.; Langenhan, J.M.; Thorson, J.S. "Sweetening” natural products via glycorandomization. Curr. Opin. Biotechnol. 2005, 16, 622-630.

22. Engelhardt, K.; Degnes, K.F.; Kemmler, M.; Bredholt, H.; Fjaervik, E.; Klinkenberg, G.; Sletta, H.; Ellingsen, T.E.; Zotchev, S.B. Production of a new thiopeptide antibiotic, TP-1161, by a marine Nocardiopsis species. Appl. Environ. Microbiol. 2010, 76, 4969-4976.

(C) 2013 by the authors; licensee MDPI, Basel, Switzerland. This article is an open access article distributed under the terms and conditions of the Creative Commons Attribution license (http://creativecommons.org/licenses/by/3.0/). 